University of Nebraska - Lincoln

DigitalCommons@University of Nebraska - Lincoln

1988

Duck Nest Success in the Prairie Pothole Region

\author{
Albert T. Klett \\ USGS Northern Prairie Wildlife Research Center \\ Terry L. Shaffer \\ USGS Northern Prairie Wildlife Research Center, tshaffer@usgs.gov \\ Douglas $\mathrm{H}$. Johnson \\ USGS Northern Prairie Wildlife Research Center, Douglas_H_Johnson@usgs.gov
}

Follow this and additional works at: https://digitalcommons.unl.edu/usgsnpwrc

Part of the Other International and Area Studies Commons

Klett, Albert T.; Shaffer, Terry L.; and Johnson, Douglas H., "Duck Nest Success in the Prairie Pothole Region" (1988). USGS Northern Prairie Wildlife Research Center. 218.

https://digitalcommons.unl.edu/usgsnpwrc/218

This Article is brought to you for free and open access by the US Geological Survey at DigitalCommons@University of Nebraska - Lincoln. It has been accepted for inclusion in USGS Northern Prairie Wildlife Research Center by an authorized administrator of DigitalCommons@University of Nebraska - Lincoln. 
This article is a U.S. government work, and is not subject to copyright in the United States.

\title{
DUCK NEST SUCCESS IN THE PRAIRIE POTHOLE REGION
}

\author{
ALBERT T. KLETT, U.S. Fish and Wildlife Service, Northern Prairie Wildlife Research Center, Jamestown, ND 58402 \\ TERRY L. SHAFFER, U.S. Fish and Wildlife Service, Northern Prairie Wildlife Research Center, Jamestown, ND 58402 \\ DOUGLAS H. JOHNSON, U.S. Fish and Wildlife Service, Northern Prairie Wildlife Research Center, Jamestown, ND 58402
}

\begin{abstract}
We estimated nest success of mallard (Anas platyrhynchos), gadwall (A. strepera), blue-winged teal (A. discors), northern shoveler (A. clypeata), and northern pintail (A. acuta) for 5 regions in North Dakota, South Dakota, and Minnesota, for 1-3 periods between 1966 and 1984, and for 8 habitat classes. We obtained composite estimates of nest success for regions and periods by weighting each habitat proportional to the number of nest initiations. The distribution of nest initiations was derived from estimates of breeding populations, preferences of species for nesting habitats, and availability of habitats. Nest success rates ranged from $<5$ to $36 \%$ among regions, periods, and species. Rates were lowest in western Minnesota (MNW) and eastern North Dakota (NDE), intermediate in central North Dakota (NDC) and eastern South Dakota (SDE), and highest in central South Dakota (SDC). In regions with comparable data, no consistent trend in nest success was apparent from early to late periods. Gadwalls and blue-winged teal nested more successfully than mallards and pintails; the relative success of shovelers varied regionally. Ducks nesting in idle grassland were the most successful and those nesting in cropland were least successful. Mammalian predation was the major cause of nesting failure (54-85\%) in all habitats, but farming operations resulted in 37 and $27 \%$ of the nesting failures in cropland and hayland, respectively. Most of the populations studied were not self-sustaining.
\end{abstract}

The Prairie Pothole Region of the northcentral United States and southcentral Canada is vital to the production of North American ducks; it contains only $10 \%$ of the continental breeding range but produces about $50 \%$ of the ducks (Smith et al. 1964). Duck production, however, has varied greatly among years because of changes in abundance of wetlands caused by erratic precipitation patterns (Crissey 1969) and because many wetlands have been drained. Agriculture and predators also affect duck production. Because of recent declines in numbers of several waterfowl species (U.S. Fish and Wildl. Serv. 1986) and low nest success rates documented in unpublished studies, biologists are concerned that too few ducks are being pro- duced in the Prairie Pothole Region to maintain breeding populations at current levels.

Nest success rate is a critical determinant of duck production and size of the fall flight (Cowardin and Johnson 1979, Johnson et al. 1987). Mortality of females, which is inversely related to nest success, and mortality of ducklings are also important factors.

The purpose of our study was to make regional estimates of nest success of mallard, gadwall, blue-winged teal, northern shoveler, and northern pintail from $>15,000$ records of nests found in the United States portion of the Prairie Pothole Region (Fig. 1). Supplemental information on breeding population levels, nesting habitat availability, and habitat use by nesting 


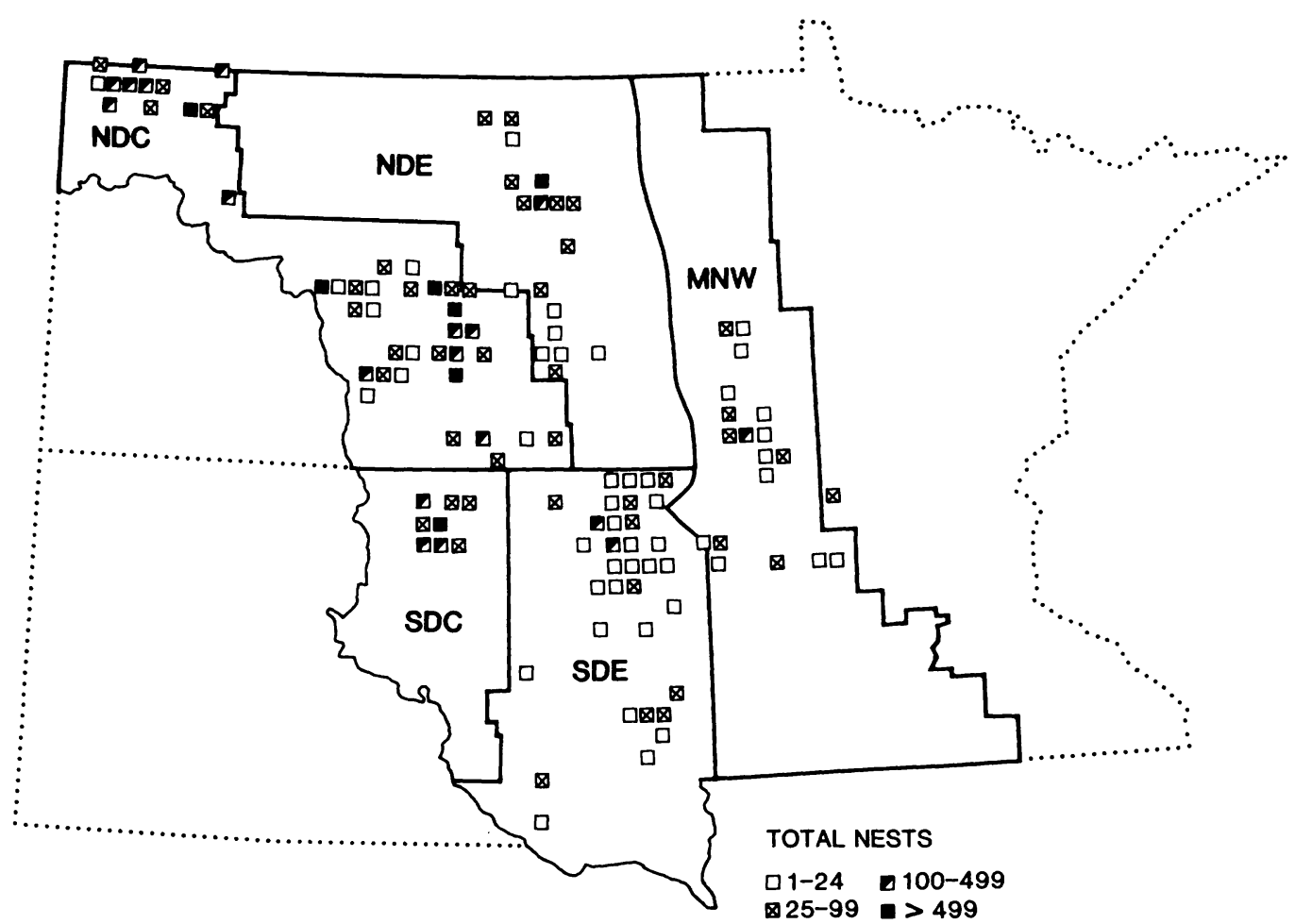

Fig. 1. Distribution of duck nests sampled in eastern North Dakota (NDE), central North Dakota (NDC), eastern South Dakota (SDE), central South Dakota (SDC), and western Minnesota (MNW) during 1966-84.

ducks was also collected to account for differences among species and to overcome unrepresentative sampling efforts among regions, habitats, and time periods.

We acknowledge the numerous cooperators who contributed nest records for entry into the Northern Prairie Wildlife Research Center (NPWRC) nest record file, particularly personnel of NPWRC, National Wildlife Refuges and Wetland Management Districts, Mid-Continent Waterfowl Management Unit, and state wildlife agencies in the Central Flyway. K. F. Higgins, H. W. Miller, M. J. Rabenberg, and A. B. Sargeant reviewed the manuscript.

\section{STUDY AREA AND METHODS}

Duck nesting data were obtained from MNW and portions of North Dakota and South Dakota east and north of the Missouri River. For analysis, these states were divided into 5 geographical regions: MNW, NDE, NDC, SDE, and SDC (Fig. 1). Regions in North Dakota and South Dakota were divided by county lines nearest the eastern or northern edge of the Missouri Coteau (Stewart and Kantrud 1973, Brewster et al. 1976).

Within each region, data were partitioned into 3 time periods and 8 habitat classes. The periods considered in the regions were 196674 (NDE, NDC, SDE, and SDC), 1975-79 (NDE and NDC), and 1980-84 (NDE, NDC, MNW, and SDE).

The 8 habitat classes used were grassland, idle grassland, hayland, planted cover, wetland, cropland, right-of-way, and odd area. Grassland is native prairie used for pasture or mowed for hay and includes planted grasses used for pasture. Idle grassland is native upland prairie on which no haying or grazing occurred during the current or preceding growing season. Hayland is planted crops mowed for forage. Herbaceous plantings established for wildlife or soil protection were called planted cover. Wetland includes the wet meadow, shallow marsh, and deep marsh zones of wetlands defined by Stewart and Kantrud (1971). Cropland is annually tilled fields of small grain or row crops. Right-of-way includes the cover between the outside right-ofway boundaries of roads, railroads, and canals. Miscellaneous habitat features such as rock piles, haystacks, gravel pits, and shelterbelts were called odd area.

Data collection followed procedures de- 
scribed by Klett et al. (1986). We defined a nest as a clutch of $\geq 1 \mathrm{egg}$. Nests that were terminated when found were not used to compute nest success. Most nests were found by flushing females with a cable-chain device towed between 2 vehicles (Higgins et al. 1977). Some were found with other types of drags or by searching cover on foot. Most units of cover were systematically searched 1-4 times, but some nests were found fortuitously or by locating radiomarked females. Nests were revisited $\geq 1$ time to determine their fate.

Data recorded for each nest were species, year, habitat class, number of eggs and incubation stage when found, complete clutch size if known, fate (successful, destroyed, abandoned, or unknown), and cause of nesting failure if known. Incubation stage was determined by candling eggs (Weller 1956). A nest was considered successful if $\geq 1$ egg hatched. A clutch was recorded as destroyed if no ducklings hatched and there was evidence of broken or missing eggs; usually all eggs were destroyed or missing. Intact clutches no longer tended by a female were considered abandoned. The fate of some nesting attempts was not determined, usually because the nest was not relocated. We also recorded dates needed to estimate nest success: date found, dates of subsequent visits when the clutch was still viable, and date of final visit when fate was determined.

\section{Estimates of Nest Success}

We calculated daily nest survival rates (DSR) for each combination of region, period, habitat, and species using the Mayfield (1961, 1975) method as modified by Johnson (1979). Nests were excluded from the analysis if they were from areas where organized predator removal or predator exclusion was likely to have increased waterfowl production.

The variance of an estimated DSR is inversely proportional to the number of exposure days involved (Johnson 1979). Among the various categories of nests, there was great variation in the number of exposure days and in the precision of the estimates. We used a linear model fit by the method of least squares (Snedecor and Cochran 1980) to improve imprecise estimates. The linear model allowed us to examine and exploit various relations among the categories of nests. Each value of DSR was weighted by the number of exposure days. We tested for significant $(P<$ 0.05 ) main effects and 2-way interactions using analysis of variance and then fit a model with only significant effects included. Significant effects included main effects for region, period, habitat, and species, and interactions between region and species, period and habitat, and habitat and species. Because interactions between period and region and between period and species were not significant $(P>0.05)$, we concluded that differences in nest success among regions and among species were similar in all periods. We assumed that differences in success among habitats were similar for all regions. This assumption was necessary to estimate nest success for all habitats in all regions. As a consequence, for a given species and period, the habitat rankings were identical in each region. Therefore, the habitat differences presented from combined data for North Dakota apply to all regions.

Nest success was calculated by raising the model's predicted DSR to a power equal to the mean laying plus incubation periods for successful clutches. We used 35 days for mallards and gadwalls, 34 days for blue-winged teal and shovelers, and 32 days for pintails. Combined nest success estimates were obtained from weighted means of the constituent estimates. Weighting was needed to account for the number of nests in each habitat, the preference for each habitat, and the availability of habitats.

For each species in each region and period, nest initiations were apportioned among the various habitats as follows: let $\hat{\theta}_{i}=$ an estimate of the preference of the species for nesting in habitat $i$ (described below), and $A_{i}=$ an estimate of availability of habitat $i$. The proportion of total nests initiated in habitat $i$ is estimated by $P_{i}=\hat{\theta}_{i} A_{i} / \Sigma \hat{\theta}_{i} A_{i}$, where $P_{i}$ is the product of preference and availability scaled so that $\Sigma P_{i}=1$.

Breeding Populations. - The number of nest initiations (initial and renesting attempts) by a given species in a particular region and period was considered to be proportional to the size of its breeding population. We therefore used estimates of breeding populations as weights for combining regions and periods. We used aerial survey data from the U.S. Fish and Wildlife Service (FWS) (Martin et al. 1979) to estimate mean annual breeding populations of each species in NDE and NDC by period. Estimates of breeding populations in other regions were not required because nest success data were not available for all periods.

The FWS reports breeding populations for 3 
zones in North Dakota. We estimated mean pair densities for each zone and multiplied the mean densities by the size of the area that was encompassed by our regional boundaries. We then summed all estimates within each region to obtain estimates for the entire region. Annual estimates for each period were multiplied by the number of years involved to obtain numbers of breeding ducks.

Habitat Preference.-We defined the preference of a particular species for a certain habitat as the probability that a female will select that habitat for nesting, given that all habitats are equally available. Cowardin et al. (1985) examined the relative preference of mallards nesting in central North Dakota for 6 of the 8 habitats used in this analysis. That information and a relation between vegetation height and density, and mallard nest densities (Kirsch et al. 1978), were used in a stochastic model of mallard productivity (Cowardin et al. 1983). We executed the model on a data set with equal availabilities of all habitat classes to estimate relative preferences of the mallard for each of the 8 habitats.

We used the estimates of mallard preference described above in combination with data from the nest record file to estimate preference values for the other species. Because we did not know the area of each habitat that was searched for nests, we could not calculate relative densities directly from the nest record file. Instead, we assumed that within each habitat the proportion of nests found during search activities was similar for all species. To minimize the bias arising from species differences in nesting chronology, we used only nests that were found in habitats that were searched $\geq 2$ times in NDC. Habitat preferences in NDC were applied to other regions that lacked sufficient samples of nests in all habitats to permit similar analysis.

For 2 habitats (e.g., $A$ and $B$ ) let $\theta_{A}$ and $\theta_{B}=$ the true mallard preference values for $A$ and $B$, respectively; $\theta_{A}+\theta_{B}=1$. Let $N_{A}$ and $N_{B}=$ the number of mallard nests found in habitats $A$ and $B$, respectively. If equal areas of $A$ and $B$ were searched, then $\mathrm{E}\left(N_{A}\right) / \mathrm{E}\left(N_{B}\right)=\theta_{A} / \theta_{B}$, where $\mathrm{E}(N)$ denotes the expected value. If, however, unequal areas of each were searched, then:

$$
\mathrm{E}\left(N_{A}\right) / \mathrm{E}\left(N_{B}\right)=K \theta_{A} / \theta_{B},
$$

where $K$ is the ratio of the area of $A$ that was searched to that of $B$. Similarly:

$$
\mathrm{E}\left(N^{\prime}{ }_{A}\right) / \mathrm{E}\left(N_{B}^{\prime}\right)=K \theta_{A}^{\prime} / \theta_{B}^{\prime},
$$

where the prime denotes a species other than the mallard. Solving equations (1) and (2) for $K$, and equating the resulting expressions, we arrive at the following expression for $\theta_{B}^{\prime} / \theta_{A}^{\prime}$ :

$$
\theta_{B}^{\prime} / \theta^{\prime}{ }_{A}=N_{A} \theta_{B} N_{B}^{\prime} / N_{B} \theta_{A} N_{A}^{\prime},
$$

where $\mathrm{E}\left(N_{A}\right), \mathrm{E}\left(N_{B}\right), \mathrm{E}\left(N^{\prime}{ }_{A}\right)$, and $\mathrm{E}\left(N_{B}^{\prime}\right)$ have been replaced by $N_{A}, N_{B}, N_{A}^{\prime}$, and $N_{B}^{\prime}$, respectively. Substituting the previously obtained estimates of mallard preference for $\theta_{A}$ and $\theta_{B}$ in equation (3) and using $\theta^{\prime}{ }_{A}+\theta^{\prime}{ }_{B}=1$, we obtain the following estimators for $\theta_{A}^{\prime}$ and $\theta_{B}^{\prime}$ : $\hat{\theta}_{A}^{\prime}=$ $N^{\prime} \hat{\theta}_{A} N_{B} /\left(N_{A} \hat{\theta}_{B} N_{B}^{\prime}+N_{A}^{\prime} \hat{\theta}_{A} N_{B}\right.$, and $\hat{\theta}_{B}^{\prime}=1-\hat{\theta}_{A}^{\prime}$.

This method for providing estimates of preferences between 2 habitats is easily extended to estimates for $\geq 3$ habitats. For $n$ habitats, there are $n-1$ linearly independent preference values that can be estimated by solving a system of $n-1$ linear equations such as equation (3).

Habitat Availability. - Availability of nesting habitats in the 5 regions for $1980-84$ was estimated from a stratified random sample of plots selected for a mallard model developed at NPWRC (Cowardin et al. 1983). Each plot was a $10.36-\mathrm{km}^{2}$ block where the area of each habitat class was determined by interpretation of aerial photographs. Estimates from these samples were adjusted to include planted cover and idle grassland habitats that were not distinguished in the mallard model. The area of these habitats for all periods was derived from unpublished annual reports of the FWS Division of Realty (K. F. Higgins and D. A. Davenport, unpubl. rep., NPWRC, 1977), and U.S. Department of Agriculture program summaries. Changes in amounts of planted cover and idle grassland were caused by government programs designed to establish cover for wildlife or to protect retired cropland from erosion.

Amounts of wetland and grassland during 1966-74 and 1975-79 were extrapolated from the 1980-84 data. Loss rates of wetlands were derived from Cowardin et al. (NPWRC, unpubl. data). Loss of range and pasture land in North Dakota from 1958 to 1977 (U.S. Dep. Agric., N.D. Multiyear Plan for Resour. Conserv., unpubl. rep., undated) was used to estimate the amount of grassland present in North Dakota and South Dakota during earlier periods. We assumed that the amounts of right-of-way, hay- 
Table 1. Availability (\%) of 8 nesting habitats for mallard, gadwall, blue-winged teal, northern shoveler, and northern pintail by region and period.

\begin{tabular}{|c|c|c|c|c|c|c|c|c|}
\hline $\begin{array}{l}\text { Region } \\
\text { Period }\end{array}$ & Cropland & Hayland & Grassland & Idle grassland & Planted cover & Right-of-way & Wetland & Odd area \\
\hline \multicolumn{9}{|c|}{ Minn. west (MNW) } \\
\hline $1980-84$ & 77.5 & 2.8 & 5.5 & 0.1 & 0.6 & 2.3 & 2.5 & 8.8 \\
\hline \multicolumn{9}{|c|}{ N.D. east (NDE) } \\
\hline $1966-74$ & 77.3 & 2.5 & 7.5 & 0.1 & 2.4 & 2.1 & 4.0 & 4.0 \\
\hline $1975-79$ & 79.7 & 2.5 & 6.9 & 0.3 & 0.7 & 2.1 & 3.8 & 4.0 \\
\hline $1980-84$ & 79.8 & 2.5 & 6.7 & 0.4 & 0.7 & 2.1 & 3.7 & 4.0 \\
\hline \multicolumn{9}{|c|}{ N.D. central (NDC) } \\
\hline $1966-74$ & 57.0 & 3.4 & 29.7 & 0.4 & 2.0 & 1.2 & 4.8 & 1.6 \\
\hline $1975-79$ & 60.2 & 3.4 & 27.7 & 0.7 & 0.6 & 1.2 & 4.6 & 1.6 \\
\hline $1980-84$ & 60.8 & 3.4 & 27.2 & 0.7 & 0.6 & 1.2 & 4.4 & 1.6 \\
\hline \multicolumn{9}{|c|}{ S.D. east (SDE) } \\
\hline $1966-74$ & 54.7 & 2.9 & 30.9 & $<0.1$ & 2.0 & 1.8 & 4.2 & 3.5 \\
\hline $1980-84$ & 58.6 & 2.9 & 28.6 & 0.2 & 0.5 & 1.8 & 3.8 & 3.5 \\
\hline \multicolumn{9}{|c|}{ S.D. central (SDC) } \\
\hline $1966-74$ & 42.1 & 4.8 & 46.2 & $<0.1$ & 1.4 & 1.1 & 3.3 & 1.2 \\
\hline
\end{tabular}

land, and odd area habitats were similar in all periods.

\section{RESULTS}

Cropland composed most of the available habitat in all regions except SDC (Table 1). The percent of cropland was greatest in MNW and NDE. Grassland was the most available habitat in SDC, a major component in NDC and SDE, and least available in MNW and NDE. Each of the other habitats composed $<5 \%$ of the available habitat in all regions except in MNW, where odd area, including woodland, made up about $9 \%$. Idle grassland composed $<1 \%$ of all available habitats in all regions.

The composition of available nesting habitats was compared among 3 periods in NDE and NDC and between 2 periods in SDE. The most important change in habitat composition was the loss of planted cover that occurred after 1966-74 as a result of the expiration of cropland retirement programs. Conversion of planted cover, grassland, and wetland to cropland during 1975-79 resulted in slight increases $(<4 \%)$ in the availability of cropland.

\section{Nesting Results}

Species Accounts. - The nesting habitat most preferred by mallards was planted cover; odd area ranked second and cropland was the least preferred (Table 2). Mallard nest success was highest in SDC, intermediate in NDC and SDE, and lowest in MNW and NDE (Table 3). Success did not vary appreciably among periods. Mallards and all other duck species studied (Table idle grassland; the habitat ranked second was planted cover in 1966-74, grassland in 197579 , and wetland in 1980-84 (Table 4). Mallards were least successful in cropland followed by hayland, odd area, and right-of-way. Predation was the principal cause of nest failure for mallards and all other duck species studied (Table 5).

Preferences of gadwalls for nesting habitats were similar to those of mallards (Table 2). Nest success of gadwalls was about $2 \times$ that of mallards except in SDC, where it was about $30 \%$

Table 2. Relative preference of mallard, gadwall, blue-winged teal, northern shoveler, and northern pintail for 8 classes of nesting habitat in central North Dakota.

\begin{tabular}{|c|c|c|c|c|c|}
\hline Habitat & Mallard & Gadwall & $\begin{array}{c}\text { Blue- } \\
\text { winged } \\
\text { teal }\end{array}$ & $\begin{array}{l}\text { Northern } \\
\text { shoveler }\end{array}$ & $\begin{array}{l}\text { Northern } \\
\text { pintail }\end{array}$ \\
\hline Cropland & $0.3^{a}$ & 0.2 & 0.3 & 0.2 & 5.4 \\
\hline Hayland & 10.7 & 13.1 & 8.4 & 6.8 & 14.2 \\
\hline Grassland & 4.5 & 6.7 & 11.8 & 10.0 & 8.5 \\
\hline Idle grassland & 6.7 & 4.9 & 4.9 & 3.0 & 2.8 \\
\hline Planted cover & 42.8 & 43.0 & 39.1 & 45.2 & 43.5 \\
\hline Right-of-way & 7.6 & 6.0 & 6.7 & 8.4 & 9.1 \\
\hline Wetland & 9.7 & 12.7 & 12.9 & 12.1 & 6.8 \\
\hline Odd area & 17.7 & 13.4 & 15.9 & 14.3 & 9.7 \\
\hline
\end{tabular}

a Preference of a species for a habitat is the probability that a $\mathrm{F}$ will select that habitat for nesting, given that all habitats are equally available. 
Table 3. Estimated percent nest success ( $n=$ no. nests) of mallard, gadwall, blue-winged teal, northern shoveler, and northern pintail by region and period.

\begin{tabular}{|c|c|c|c|c|c|c|c|c|c|c|}
\hline \multirow{2}{*}{$\begin{array}{l}\text { Region } \\
\text { Period }\end{array}$} & \multicolumn{2}{|c|}{ Mallard } & \multicolumn{2}{|c|}{ Gadwall } & \multicolumn{2}{|c|}{ Blue-winged teal } & \multicolumn{2}{|c|}{ Shoveler } & \multicolumn{2}{|c|}{ Pintail } \\
\hline & $\%$ & $n$ & $\%$ & $n$ & $\%$ & $n$ & $\%$ & 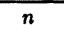 & $\%$ & $\bar{n}$ \\
\hline \multicolumn{11}{|c|}{ Minn. west (MNW) } \\
\hline $1980-84$ & 5 & 90 & 10 & 13 & 16 & 620 & 1 & 11 & 6 & 13 \\
\hline \multicolumn{11}{|c|}{ N.D. east (NDE) } \\
\hline $1966-74$ & 5 & 46 & 9 & 52 & 10 & 216 & 5 & 12 & 5 & 54 \\
\hline $1975-79$ & 5 & 158 & 12 & 174 & 13 & 444 & 7 & 92 & 6 & 184 \\
\hline $1980-84$ & 5 & 20 & 11 & 19 & 12 & 94 & 5 & 6 & 7 & 6 \\
\hline \multicolumn{11}{|c|}{ N.D. central (NDC) } \\
\hline $1966-74$ & 8 & 210 & 14 & 373 & 12 & 1,010 & 16 & 82 & 9 & 162 \\
\hline $1975-79$ & 11 & 1,036 & 21 & 979 & 20 & 2,449 & 26 & 411 & 13 & 503 \\
\hline $1980-84$ & 10 & 929 & 18 & 907 & 16 & 1,180 & 19 & 268 & 13 & 310 \\
\hline \multicolumn{11}{|c|}{ S.D. east (SDE) } \\
\hline $1966-74$ & 9 & 51 & 19 & 72 & 21 & 393 & 12 & 14 & 3 & 10 \\
\hline $1980-84$ & 10 & 79 & 23 & 52 & 27 & 382 & 15 & 21 & 5 & 27 \\
\hline \multicolumn{11}{|c|}{ S.D. central (SDC) } \\
\hline $1966-74$ & 19 & 487 & 25 & 386 & 29 & 378 & 36 & 69 & 19 & 122 \\
\hline
\end{tabular}

higher (Table 3). Regional differences in gadwall nest success were similar to those of mallards. Gadwalls were most successful in cropland and idle grassland (Table 4). Gadwalls were more successful than mallards in all habitats except idle grassland, where success was similar to that of mallards. Gadwalls nesting in hayland, rightof-way, and wetland were least successful.

Blue-winged teal also preferred planted cover over other habitat classes (Table 2). Blue-winged teal were more selective for grassland than mallards, gadwalls, and pintails. Cropland was least preferred. Nest success of blue-winged teal was similar to that of gadwall except in MNW, where it was $60 \%$ higher (Table 3 ). Success was highest in SDE and SDC and lowest in NDE. Among habitats, success was lowest in cropland and varied little among the other 7 habitats (Table 4).

Nesting habitat preferences of shovelers were similar to those of blue-winged teal (Table 2). Nest success of shovelers was low and comparable to that of mallards in MNW, NDE, and SDE (Table 3). In NDC and SDC, success of shovelers was higher than for any other species. Shovelers were most successful in grassland and idle grassland and least successful in hayland and wetland (Table 4).

Preferred habitat of the pintail was planted cover; hayland ranked second and idle grassland was the least preferred (Table 2). The preference of pintails for cropland was greater than that of the other species. Preference for cropland, although lower than for most other habi- tats, is important because cropland is highly available. Among regions, nest success rates for pintails were generally low and comparable to those of mallards (Table 3). Success was somewhat higher for pintails than for mallards in cropland and grassland (Table 4). Nest success in other habitats was similar for both species. In addition to predation, destruction by farm machinery also was an important cause of pintailnest loss (Table 5).

Regional and Temporal Differences in Nest Success.-Our results suggest the following regional gradient in nest success (from lowest to highest): (1) MNW and NDE, (2) NDC, (3) SDE, (4) SDC (Table 3). Important exceptions were that nest success rates for blue-winged teal in MNW were similar to those in NDC, rates for pintails in SDE were similar to those in MNW, and rates for shovelers in SDE were lower than in NDC.

In regions where comparable data were available, nest success for gadwalls, blue-winged teal, and shovelers tended to be lowest in 1966-74 and highest in 1975-79; this trend was most evident in NDC (Table 3). Differences among periods were small for mallards and pintails.

Nesting Results by Habitat. - We combined data from NDE and NDC to illustrate differences in nesting success among habitats. Samples in these 2 regions were larger and had better spatial and temporal distributions than the other regions.

Cropland was the most common habitat (Ta- 
Table 4. Estimated percent nest success, number of nests $(n)$, and percent of nest initiations ( () by habitat for mallard, gadwall, blue-winged teal, northern shoveler, and northern pintail in North Dakota, 1966-84.

\begin{tabular}{|c|c|c|c|c|c|c|c|c|c|c|c|c|c|c|c|}
\hline \multirow{2}{*}{$\begin{array}{l}\text { Habitat } \\
\text { Period }\end{array}$} & \multicolumn{3}{|c|}{ Mallard } & \multicolumn{3}{|c|}{ Gadwall } & \multicolumn{3}{|c|}{ Blue-winged Teal } & \multicolumn{3}{|c|}{ Shoveler } & \multicolumn{3}{|c|}{ Pintail } \\
\hline & $\%$ & $n$ & I & $\%$ & $n$ & I & $\%$ & $n$ & I & $\%$ & $n$ & I & $\%$ & $n$ & $\bar{I}$ \\
\hline \multicolumn{16}{|l|}{ Cropland } \\
\hline $1966-74$ & 1 & 5 & 7 & 20 & 6 & 3 & 6 & 26 & 5 & 7 & 3 & 3 & 5 & 53 & 51 \\
\hline $1975-79$ & 2 & 10 & 9 & 24 & 0 & 4 & 7 & 1 & 6 & 9 & 6 & 4 & 6 & 27 & 57 \\
\hline $1980-84$ & 3 & 4 & 9 & 41 & 1 & 4 & 12 & 6 & 6 & 15 & 0 & 4 & 11 & 27 & 57 \\
\hline \multicolumn{16}{|l|}{ Hayland } \\
\hline $1966-74$ & 2 & 0 & 9 & 3 & 1 & 10 & 7 & 4 & 5 & 2 & 0 & 5 & 2 & 0 & 6 \\
\hline $1975-79$ & 4 & 31 & 12 & 6 & 20 & 13 & 13 & 29 & 7 & 4 & 3 & 6 & 3 & 10 & 6 \\
\hline $1980-84$ & 6 & 11 & 12 & 8 & 27 & 13 & 18 & 25 & 7 & 6 & 12 & 6 & 4 & 12 & 6 \\
\hline \multicolumn{16}{|l|}{ Grassland } \\
\hline $1966-74$ & 6 & 17 & 23 & 12 & 53 & 31 & 11 & 233 & 43 & 14 & 11 & 39 & 10 & 16 & 21 \\
\hline $1975-79$ & 12 & 116 & 27 & 23 & 96 & 35 & 21 & 524 & 48 & 27 & 72 & 46 & 19 & 70 & 21 \\
\hline $1980-84$ & 8 & 76 & 26 & 15 & 127 & 35 & 14 & 201 & 47 & 18 & 63 & 46 & 13 & 69 & 21 \\
\hline \multicolumn{16}{|c|}{ Idle grassland } \\
\hline $1966-74$ & 18 & 59 & $<1$ & 18 & 142 & $<1$ & 11 & 469 & $<1$ & 16 & 35 & $<1$ & 18 & 30 & $<1$ \\
\hline $1975-79$ & 27 & 253 & 1 & 26 & 230 & 1 & 17 & 480 & 1 & 22 & 42 & $<1$ & 27 & 66 & $<1$ \\
\hline $1980-84$ & 27 & 466 & 1 & 27 & 313 & 1 & 17 & 437 & 1 & 22 & 69 & $<1$ & 27 & 89 & $<1$ \\
\hline \multicolumn{16}{|c|}{ Planted cover } \\
\hline $1966-74$ & 10 & 156 & 28 & 14 & 202 & 26 & 13 & 405 & 20 & 12 & 41 & 25 & 10 & 105 & 13 \\
\hline $1975-79$ & 10 & 660 & 11 & 13 & 740 & 10 & 13 & 1,608 & 7 & 12 & 336 & 9 & 10 & 454 & 4 \\
\hline $1980-84$ & 9 & 272 & 11 & 12 & 377 & 11 & 12 & 482 & 8 & 11 & 96 & 10 & 9 & 97 & 5 \\
\hline \multicolumn{16}{|c|}{ Right-of-way } \\
\hline $1966-74$ & 4 & 11 & 4 & 7 & 12 & 3 & 11 & 24 & 3 & 6 & 3 & 4 & 6 & 5 & 2 \\
\hline $1975-79$ & 5 & 63 & 5 & 10 & 39 & 4 & 15 & 148 & 3 & 9 & 33 & 5 & 9 & 45 & 2 \\
\hline $1980-84$ & 5 & 57 & 5 & 9 & 31 & 4 & 13 & 50 & 3 & 8 & 13 & 5 & 8 & 8 & 2 \\
\hline \multicolumn{16}{|l|}{ Wetland } \\
\hline $1966-74$ & 7 & 2 & 13 & 10 & 4 & 15 & 11 & 44 & 13 & 3 & 0 & 13 & 5 & 6 & 4 \\
\hline $1975-79$ & 7 & 20 & 15 & 9 & 8 & 18 & 10 & 43 & 14 & 3 & 4 & 15 & 5 & 2 & 4 \\
\hline $1980-84$ & 12 & 37 & 15 & 16 & 28 & 18 & 17 & 51 & 14 & 5 & 14 & 15 & 8 & 8 & 4 \\
\hline \multicolumn{16}{|l|}{ Odd area } \\
\hline $1966-74$ & 5 & 6 & 16 & 17 & 5 & 11 & 14 & 21 & 11 & 9 & 1 & 11 & 6 & 1 & 4 \\
\hline $1975-79$ & 5 & 41 & 20 & 18 & 20 & 15 & 15 & 60 & 14 & 10 & 7 & 14 & 7 & 13 & 4 \\
\hline $1980-84$ & 3 & 26 & 20 & 12 & 22 & 15 & 10 & 22 & 14 & 7 & 7 & 14 & 5 & 6 & 4 \\
\hline \multicolumn{16}{|l|}{ Total } \\
\hline $1966-74$ & 6 & 256 & 100 & 12 & 425 & 100 & 11 & 1,226 & 100 & 10 & 94 & 100 & 7 & 216 & 100 \\
\hline $1975-79$ & 8 & 1,194 & 100 & 16 & 1,153 & 100 & 17 & 2,893 & 100 & 16 & 503 & 100 & 9 & 687 & 100 \\
\hline $1980-84$ & 7 & 949 & 100 & 15 & 926 & 100 & 14 & 1,274 & 100 & 13 & 274 & 100 & 10 & 316 & 100 \\
\hline
\end{tabular}

ble 1) but the least preferred for nesting by all species except pintail (Table 2). The relative preference of nesting pintails for cropland was about $5 \%$ compared with $<0.5 \%$ for the other species. Cropland was also the most important nesting habitat for pintails; $51-57 \%$ of their nests were located there (Table 4). Cropland accounted for $<10 \%$ of the nests initiated by the other species. Nests of blue-winged teal $(n=33)$ and pintails $(n=107)$ made up $80 \%$ of all nests found in cropland. Nest success of these 2 species in cropland ranged from 5 to $12 \%$ (Table 4). Nest success of mallards in cropland was $<5 \%$ in all periods. Success rates for gadwalls and shovelers were derived from small samples and may not be meaningful. Most of the nest losses occurring in cropland were caused by predation or farming operations (Table 5).

Hayland composed $3 \%$ of the available nesting cover. Roughly $10 \%$ of the nest initiations of mallards and gadwalls but $<8 \%$ of those of the other species were in hayland (Table 4). Nest success of mallards, gadwalls, shovelers, and pintails was always $<10 \%$ and most often $<5 \%$ 
Table 5. Outcomes of nesting attempts by 5 species of ducks and in 8 habitats in North Dakota, 1966-84.

\begin{tabular}{lrrrr}
\hline & Success- & \multicolumn{4}{c}{ Unsuccessful (\%) } \\
\cline { 4 - 6 } & ful (\%) & Predation Machines & Other $^{\mathrm{a}}$ \\
\hline Species & & & & \\
$\quad$ Mallard & 7 & 82 & 7 & 4 \\
Gadwall & 13 & 77 & 5 & 4 \\
Blue-winged teal & 13 & 78 & 4 & 4 \\
Northern shoveler & 12 & 79 & 4 & 5 \\
Northern pintail & 8 & 67 & 22 & 3 \\
Habitat & & & & \\
Cropland & 7 & 54 & 37 & 3 \\
Hayland & 6 & 66 & 27 & 2 \\
Grassland & 14 & 81 & $<1$ & 5 \\
Idle grassland & 21 & 76 & $<1$ & 3 \\
Planted cover & 12 & 85 & $<1$ & 3 \\
Right-of-way & 8 & 81 & 5 & 6 \\
Wetland & 9 & 81 & 2 & 8 \\
Odd area & 10 & 83 & 3 & 4 \\
All habitats & & & & \\
and species & 11 & 77 & 8 & 4 \\
\hline
\end{tabular}

a Other includes weather, fire, livestock, and unknown.

(Table 4). Blue-winged teal were more successful in hayland than the other 4 species. Most nest losses were caused by predation but losses caused by haying operations were also important (Table 5).

Grassland was the second most available nesting habitat (Table 1). In most periods, mallards, gadwalls, blue-winged teal, and shovelers initiated more nests in grassland than any other habitat. Use of grassland by nesting pintails ranked second after cropland (Table 4). Nest success in grassland was above average for shovelers and pintails and about average for the other species.

Less than $2 \%$ of all nest initiations occurred in idle grassland (Table 4), reflecting its scarcity (Table 1) and low preference value (Table 2). Nest success of all species was comparatively high in idle grassland.

Planted cover was the nesting habitat most preferred by all species (Table 2), but like idle grassland it composed a small part of the available habitat (Table 1). During 1966-74, approximately $25 \%$ of all mallard, gadwall, and shoveler nests were initiated in planted cover (Table 4). The importance of planted cover to nesting ducks declined when it became less available after 1966-74. In comparison to other habitats, nest success in planted cover was about average and was fairly stable throughout all periods.
Relatively few nests were initiated in rightof-way (Table 4) because of its scarcity (Table 1). Nest success in right-of-way was generally low compared to that in other habitats (Table 4).

The availability of wetland ranked third after cropland and grassland (Table 1). Fewer than $5 \%$ of all pintail nests were initiated in wetland; initiations by the other species ranged from 13 to $18 \%$ (Table 4). Compared with other habitats, nest success in wetland was about average for mallards, gadwalls, and blue-winged teal but below average for shovelers and pintails (Table 4). Estimates of nest initiations and nest success were biased because most of the nest searches were conducted in the wet meadow zone, hence, few overwater nests are included in the sample. The bias would affect species estimates differently. Of the species studied, the mallard is the most prone to nest overwater (Evans and Black 1956:39, Jessen et al. 1964:59).

Odd area composed only $3 \%$ of the available habitat (Table 1) but $>10 \%$ of nest initiations for all species except pintail were in this habitat (Table 4). Nest success rates were fairly consistent among periods, but were generally average to below average, depending on the species.

\section{DISCUSSION}

The threshold level of nest success that will sustain a population depends on the survival rates of females and ducklings and the renesting rate, all of which are subject to species, regional, and temporal effects. Based on a model developed by Cowardin and Johnson (1979), Cowardin et al. (1985) concluded that nest success of about $15 \%$ will maintain a mallard population for a long term in NDC. Maintenance of populations with nest success rates $<15 \%$ requires immigration of breeding pairs from other regions. Similar estimates for other species and regions are lacking. In assessing this model, Cowardin and Johnson (1979) found that adult survival rates, nest success, and the number of renests are the most crucial parameters affecting population stability. Given roughly similar survival rates among species, the nest success rate necessary to maintain a population will depend largely on renesting potential. The threshold levels for mallards and pintails are likely similar because they nest early and are persistent renesters. The threshold for shovelers, blue-winged teal, and gadwalls is probably $>15 \%$ because they are mid- to late-season nesters and have 
less potential for renesting than mallards or pintails. Deferred nesting by some yearling gadwalls (J. T. Lokemoen et al., NPWRC, unpubl. data) also suggests a higher threshold level. To put our nest success estimates in perspective, we used the threshold level of $15 \%$ for mallards suggested by Cowardin et al. (1985) and assumed a level of $15 \%$ for pintails and $20 \%$ for the other species.

Based on the application of these criteria, nest success was inadequate to maintain populations in most regions. Exceptions were SDC for all species; NDC (1975-79) for gadwalls, bluewinged teal, and shovelers; and SDE for gadwalls (1980-84) and blue-winged teal (1966-74, 1980-84).

In NDE and NDC, no consistent increase or decrease in nest success was apparent between 1966-74 and 1980-84. In general, nest success was lowest in 1966-74 and highest in 1975-79. Differences among periods were usually $<4$ percentage points for all species, but ranged from 7 to 10 points for gadwalls, blue-winged teal, and shovelers in NDC. Gadwalls and bluewinged teal had consistently higher nest success rates than pintails and mallards. Rates for shovelers were higher than those for the other species in NDC and SDC but were similar to those for mallards in the other regions.

Nest success varied considerably among the 8 habitat classes in North Dakota (NDE and NDC combined). Success rates consistently approached or exceeded hypothetical threshold levels only in idle grassland and in grassland in 1975-79. Grassland was of major importance to all species studied because it was plentiful and nest success was relatively high. Idle grassland was of minor importance regionally because of its scarcity but may have been important locally because nest success was usually high. Wetland, odd area, and planted cover accounted for about $25 \%$ of the nest initiations by all species except pintails. Planted cover was by far the most preferred nesting habitat for all 5 species. Use was highest in 1966-74 because it was more common than in later periods. Because planted cover is highly preferred, it has a great potential for producing ducks if nest success can be increased. Nest success was usually lowest in cropland, hayland, and right-of-way. Use of these 3 habitats was generally low, but pintails initiated $>50 \%$ of their nests in cropland and mallards and gadwalls initiated between 9 and $13 \%$ of their nests in hayland. Losses of grassland, wetland, odd area, and planted cover habitats due to intensive farming practices may cause more ducks to nest in cropland and hayland where nests are exposed to increased risk by predation and farming operations.

Predators were the most important cause of nest losses in all regions and in all habitats. Farming operations caused appreciable losses in cropland and hayland. The most important egg predators common to all regions studied were red fox (Vulpes vulpes), striped skunk (Mephitis mephitis), mink (Mustela vison), raccoon (Procyon lotor), badger (Taxidea taxus), and Franklin's ground squirrel (Spermophilus franklinii) (Sargeant and Arnold 1984). Coyotes (Canis latrans) were present locally, most often in the western parts of NDC and SDC, and reduce red fox predation on female ducks and eggs (Sargeant and Arnold 1984). The same authors thought the red fox had the greatest impact on nest success of upland nesting ducks. Variation in nest success rates among regions was most likely a result of differences in the size and composition of predator populations and differences in the abundance and distribution of their alternative foods.

\section{MANAGEMENT IMPLICATIONS}

Establishing planted cover and managing native prairies are standard procedures for providing nesting cover on managed wildlife lands in the Prairie Pothole Region. Our results substantiate the value of these 2 habitats for nesting ducks. Of the 8 habitats considered, planted cover was the most preferred and success was highest for ducks nesting in idle prairie grassland. Nest success in both habitats, however, was too low to meet goals for duck production on managed lands. Region-wide, the "sodbuster," "swampbuster," and Conservation Reserve provisions of the 1985 farm bill may reduce losses of grassland and wetland habitats and increase the amount of planted cover in the Prairie Pothole Region of the United States. As a result of these programs, we predict a greater proportion of duck nests will be initiated in planted cover, as occurred in 1966-74, but a minimal impact on duck populations will occur unless mammalian predation is reduced. Predation on nesting ducks and their eggs may be reduced naturally if expanding coyote populations serve to control fox populations through competition (Sargeant and Arnold 1984). Increased use of conservation tillage, especially no-till winter 
wheat, may provide safer nesting habitat for ducks nesting in cropland. Duebbert and Kantrud (1987) reported a success rate of $29 \%$ for 150 duck nests found in 2,300 ha of no-till winter wheat in North Dakota in 1984-85.

The wetland base in the Prairie Pothole Region of the United States is adequate to attract large numbers of breeding ducks, but our results implicate low nest success as a factor limiting population maintenance or growth. Nest success in future years will vary with farming practices and predator populations unless suitable management practices can be developed and applied.

\section{LITERATURE CITED}

Brewster, W. G., J. M .Gates, and L. D. Flake. 1976. Breeding waterfowl populations and their distribution in South Dakota. J. Wildl. Manage. 40:50-59.

Cowardin, L. M., D. S. Gilmer, And C. W. ShaifFER. 1985. Mallard recruitment in the agricultural environment of North Dakota. Wildl. Monogr. 92. 37pp.

— AND D. H. Johnson. 1979. Mathematics and mallard management. J. Wildl. Manage. 43: 18-35.

$\longrightarrow,-$ A. M. Frank, AND A. T. Klett. 1983. Simulating results of management actions on mallard production. Trans. North Am. Wildl. and Nat. Resour. Conf. 48:257-272.

Crissey, W. F. 1969. Prairie potholes from a continental viewpoint. Pages 161-171 in Saskatoon wetland seminar. Can. Wildl. Serv. Rep. Ser. 6.

Duebbert, H. F., AND H. A. Kantrud. 1987. Use of no-till winter wheat by nesting ducks in North Dakota. J. Soil and Water Conserv. 42:50-53.

Evans, C. D., AND K. E. BLACK. 1956. Duck production studies on the prairie potholes of South Dakota. U.S. Fish and Wildl. Serv. Spec. Sci. Rep. 32. $59 \mathrm{pp}$.

Higgins, K. F., L. M. Kirsch, H. F. Duebbert, A. T. Klett, J. T. Lokemoen, H. W. Miller, AND A. D. KRUSE. 1977. Construction and operation of cable-chain drag for nest searches. U.S. Fish and Wildl. Serv. Wildl. Leafl. 512. 14pp.

Jessen, R. L., J. P. Lindmeier, And R. E. Farmes. 1964. A study of duck nesting and production as related to land use in Mahnomen County, Minnesota. Pages 26-82 in J. B. Moyle, ed. Ducks and land use in Minnesota. Minn. Dep. Conserv. Tech. Bull. 8.
JoHnSON, D. H. 1979. Estimating nest success: the Mayfield method and an alternative. Auk 96: 65l-661.

- D. W. Sparling, and L. M. Cowardin. 1987. A model of the productivity of the mallard duck. Ecol. Model. 38:257-275.

KirsCh, L. M., H. F. Duebbert, AND A. D. Kruse. 1978. Grazing and haying effects on habitats of upland nesting birds. Trans. North Am. Wildl. and Nat. Resour. Conf. 43:486-497.

Klett, A. T., H. F. Duebbert, C. A. FaAnes, and K. F. Higgins. 1986. Techniques for studying nest success of ducks in upland habitats in the prairie pothole region. U.S. Fish and Wildl. Serv. Resour. Publ. 158. 24pp.

Martin, F. W., R. S. Pospahala, and J. D. Nichols. 1979. Assessment and population management of North American migratory birds. Pages 187239 in J. Cairns, Jr., G. P. Patil, and W. E. Waters, eds. Environmental biomonitoring, assessment, prediction, and management - certain case studies and related quantitative issues. Int. Co-operative Publ. House, Fairland, Md.

MAYFIELD, H. 1961. Nesting success calculated from exposure. Wilson Bull. 73:255-261.

1975. Suggestions for calculating nest success. Wilson Bull. 87:456-466.

Sargeant, A. B., AND P. M. ARnold. 1984. Predator management for ducks on waterfowl production areas in the northern plains. Vertebr. Pest Conf. 11:161-167.

Smith, A. G., J. H. Stoudt, AND J. B. Gollop. 1964. Prairie potholes and marshes. Pages 39-50 in J. P. Linduska, ed. Waterfowl tomorrow. U.S. Gov. Printing Off., Washington, D.C.

SNedecor, G. W., AND W. G. Cochran. 1980. Statistical methods. Seventh ed. Iowa State Univ. Press, Ames. 507pp.

Stewart, R. E., AND H. A. Kantrud. 1971. Classification of natural ponds and lakes in the glaciated prairie region. U.S. Fish and Wildl. Serv. Resour. Publ. 99. 57pp.

$\longrightarrow$, AND - 1973. Ecological distribution of breeding waterfowl populations in North $\mathrm{Da}$ kota. J. Wildl. Manage. 37:39-50.

UNited STATES Fish AND WILdLIFE SERVICE. 1986. North American waterfowl management plan. U.S. Fish and Wildl. Serv., Washington, D.C. 33pp.

WELleR, M. W. 1956. A simple field candler for waterfowl eggs. J. Wildl. Manage. 20:111-113.

Received 16 December 1986. Accepted 20 January 1988. 